\title{
Secretarial Certificate
}

National Cancer Institute

\section{Source}

National Cancer Institute. Secretarial Certificate. NCI Thesaurus. Code C71339.

A document certifying a person to perform routine administrative, or personal tasks for a superior, including word processing, bookkeeping, file and record keeping, and scheduling. 